\title{
Antioxidative Activity of Natural Isorhapontigenin
}

\author{
Qing Li Wang ${ }^{1}$, Mao Lin $^{2}$ and Geng Tao Liu ${ }^{1, *}$ \\ ${ }^{1}$ 2nd Department of Pharmacology and ${ }^{2}$ Department of Phytochemistry, Institute of Materia Medica, Chinese Academy \\ of Medical Sciences and Peking Union Medical College, 1 Xian Nong Tan St., Beijing 100050, China
}

Received May 18, 2001 Accepted June 27, 2001

\begin{abstract}
Isorhapontigenin (ISOR), isolated from Belamcanda chinensis, is a derivative of stilbene. Its chemical structure is very similar to that of resveratrol, with a potent antioxidative effect. In the present study, we investigated the antioxidative activity of ISOR in vitro. Oxidative damage of rat liver microsomes, brain mitochondria and synaptosomes was induced by $\mathrm{Fe}^{2+}-\mathrm{Cys}$, VitC-ADP- $\mathrm{Fe}^{2+}$ and $\mathrm{H}_{2} \mathrm{O}_{2}$, respectively. The formation of malondialdehyde (MDA), decrease of reduced glutathione (GSH) and increase of ultra-weak chemiluminescence during the lipid peroxidation process were determined. In addition, the characteristic ultra-weak chemiluminescence of oxidative DNA damage induced by $\mathrm{CuSO}_{4}-\mathrm{Phen}-\mathrm{VitC}-\mathrm{H}_{2} \mathrm{O}_{2}$ system was studied. The results showed that ISOR significantly inhibited MDA formation in liver microsomes, brain mitochondria and synaptosomes induced by $\mathrm{Fe}^{2+}-\mathrm{Cys}$. Also, ISOR markedly prevented the decrease of GSH in mitochondria and synaptosomes induced by $\mathrm{H}_{2} \mathrm{O}_{2}$ and the increase of ultra-weak chemiluminescence during lipid peroxidation induced by VitC-ADP- $\mathrm{Fe}^{2+}$ as well as oxidative DNA damage induced by $\mathrm{CuSO}_{4-}$ Phen-VitC- $\mathrm{H}_{2} \mathrm{O}_{2}$. The effects of ISOR at $10^{-5}$ and $10^{-6} \mathrm{~mol} / \mathrm{L}$ on the MDA formation and decrease of GSH were similar to that of the classical antioxidant vitamin $\mathrm{E}\left(10^{-4} \mathrm{~mol} / \mathrm{L}\right)$. It may be concluded that ISOR possessed potent antioxidative activity and was much more potent than vitamin E.
\end{abstract}

Keywords: Isorhapontigenin, Antioxidant, Chemiluminescence, Oxidative DNA damage

Resveratrol (3,4,5-trihydroxystilbene), one of stilbene derivatives, is a naturally occurring phytoalexin produced by some spermatophytes such as grapevines in response to injury and fungal attack. Red wine contains abundant resveratrol, even up to $15 \mathrm{mg} / \mathrm{L}$, while white wine contains a very small amount of resveratrol because it is present in grape berry skins but not in the flesh (1). Resveratrol possesses multiple bioactivities such as anticancer activity and anti-inflammatory activity (1) and has protective effects against some diseases related to oxidative stress such as cardiovascular diseases, Parkinson's disease and Alzheimer's disease (AD) $(2,3)$. The antioxidant activity of resveratrol is closely related to the phenolic hydroxyl groups in its structure. Isorhapontigenin (ISOR, Fig. 1) isolated from Belamcanda chinensis is also a derivative of stilbene, and its chemical structure is very similar to that of resveratrol (4). It is quite possible that ISOR also has antioxidative activity. The present study was designed to investigate the antioxidant effect of ISOR.

*Corresponding author. FAX: +86-10-63017757

Email: liugtwur@public.bta.net.cn

\section{MATERIALS AND METHODS}

ISOR was prepared by M. Lin (5); its purity was over $98 \%$ and dissolved in ethanol before use. Tris, cysteine (Cys), ADP, vitamin E (Vit E), vitamin C (Vit C), o-phthaldialdehyde (OPT) and reduced glutathione (GSH) were purchased from Sigma Chemical Co. (St. Louis, MO, USA). DNA, trichloroacetic acid (TCA), thiobarbituric acid (TBA), 1,10-phenanthroline (Phen) and other chemicals were obtained from Beijing Chemical Factory (Beijing, China) and Shanghai Biochemical Factory (Shanghai, China). Both sexes of Wistar rats $(200-300 \mathrm{~g})$ were purchased from the Experiment Animal Center of Chinese Academy of Medical Sciences.

Effect of ISOR on lipid peroxidation (LPO) of rat liver microsomes

Preparation of rat liver microsomes (6): Rats were sacrificed by decapitation and $20 \%$ liver homogenate was made with ice-cold TMS buffer $(0.05 \mathrm{~mol} / \mathrm{L}$ Tris- $\mathrm{HCl}$, $3 \mathrm{mmol} / \mathrm{L} \mathrm{MgCl}_{2}$ and $0.2 \mathrm{~mol} / \mathrm{L}$ sucrose, $\mathrm{pH}$ 7.4). The suspension was centrifuged at $10,000 \times g$ for $15 \mathrm{~min}$ at $4^{\circ} \mathrm{C}$, and then the obtained supernatant was centrifuged at 


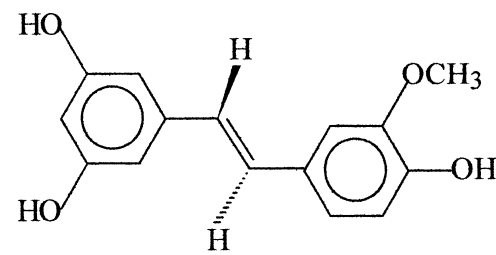

Isorhapontigenin

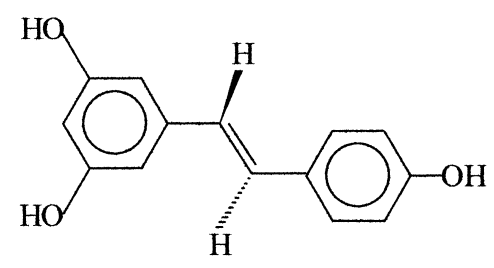

Resveratrol

Fig. 1. Chemical structures of isorhapontigenin and resveratrol.

$105,000 \times g$ for $1 \mathrm{~h}$. The pellet was resuspended in ice-cold TMS buffer. Microsomal protein was determined by the Lowry method (7). The microsomal suspensions were stored in small portions at $-70^{\circ} \mathrm{C}$.

Determination of malondialdehyde (MDA) formation in liver microsomes induced by $\mathrm{Fe}^{2+}$-Cys (8): The microsomal protein $(1 \mathrm{mg})$ was incubated with ISOR $\left(10^{-4}, 10^{-5}\right.$ and $10^{-6}$ $\mathrm{mol} / \mathrm{L})$, Vit E $\left(10^{-4} \mathrm{~mol} / \mathrm{L}\right)$ or vehicle in $1 \mathrm{ml} 0.1 \mathrm{~mol} / \mathrm{L}$ PBS (pH 7.4) at $37^{\circ} \mathrm{C}$ for $15 \mathrm{~min}$, and then $50 \mu \mathrm{mol} / \mathrm{L}$ $\mathrm{FeSO}_{4}$ and $200 \mu \mathrm{mol} / \mathrm{L}$ Cys were added; $20 \mathrm{~min}$ later, $1 \mathrm{ml}$ of $20 \%$ TCA was added and then the suspension was centrifuged at $200 \times g$ for $10 \mathrm{~min}$. The supernatant $(1 \mathrm{ml})$ was mixed with $1 \mathrm{ml} 0.67 \% \mathrm{TBA}$ and reacted in a boiling water bath for $10 \mathrm{~min}$. The absorbance was determined at $532 \mathrm{~nm}$ on a semi-automatic biochemical reader (Citizen, Tokyo).

Measurement of the ultra-weak chemiluminescence during LPO in liver microsomes induced by VitC-ADP$\mathrm{Fe}^{2+}$ (9): The microsomal protein $(2 \mathrm{mg})$ was incubated with ISOR $\left(10^{-4}, 10^{-5}\right.$ and $\left.10^{-6} \mathrm{~mol} / \mathrm{L}\right)$, Vit E $\left(10^{-4} \mathrm{~mol} / \mathrm{L}\right)$ or vehicle in $1 \mathrm{ml} 0.1 \mathrm{~mol} / \mathrm{L} \mathrm{PBS}(\mathrm{pH} 7.4)$ at $37^{\circ} \mathrm{C}$ for 15 min and then mixed with Vit C ( $1 \mathrm{mmol} / \mathrm{L})$ - ADP (4 mmol /L) $-\mathrm{FeSO}_{4}(0.2 \mathrm{mmol} / \mathrm{L})$; the intensity of ultra-weak chemiluminescence was determined immediately by a Ultra-Weak Chemiluminescence Analyzer (BPCL, Beijing, China).

\section{Effect of ISOR on oxidative damage of rat cerebral cortex} mitochondria and synaptosomes

Preparation of mitochondria and synaptosomes (10): Rats were sacrificed by decapitation and $10 \%$ cerebral cortex homogenate was made in ice-cold $0.32 \mathrm{~mol} / \mathrm{L}$ sucrose solution. The suspension was centrifuged at $4^{\circ} \mathrm{C}$, $120 \times g$ for $10 \mathrm{~min}$, and then the supernatant was centrifuged at $20,000 \times \mathrm{g}$ for $10 \mathrm{~min}$. The precipitate was resuspended in $0.32 \mathrm{~mol} / \mathrm{L}$ sucrose solution. The suspension was centrifuged by sucrose gradient centrifugation $(0.8$ and $1.2 \mathrm{~mol} / \mathrm{L}$ sucrose solution) at $150,000 \times g$ for $20 \mathrm{~min}$. The mitochondria and synaptosomes were collected from the bottom and the interface between two layers, respectively. The mitochondria and synaptosomes were resuspended in
$0.32 \mathrm{~mol} / \mathrm{L}$ sucrose solution and washed twice at $4^{\circ} \mathrm{C}$, $20,000 \times g$. The mitochondrial and synaptosomal protein was determined by the Lowry method (7). The prepared mitochondria and synaptosomes suspensions in small portions were stored at $-70^{\circ} \mathrm{C}$.

Determination of MDA formation in mitochondria and synaptosomes induced by $\mathrm{Fe}^{2+}-\mathrm{Cys}$ (11): The mitochondrial and synaptosomal protein $(0.1 \mathrm{mg})$ were incubated with ISOR $\left(10^{-5}, 10^{-6}\right.$ and $\left.10^{-7} \mathrm{~mol} / \mathrm{L}\right)$, Vit E $\left(10^{-4} \mathrm{~mol} / \mathrm{L}\right)$ or vehicle in $1 \mathrm{ml} 0.1 \mathrm{~mol} / \mathrm{L} \mathrm{PBS}(\mathrm{pH} 7.4)$ at $37^{\circ} \mathrm{C}$ for $15 \mathrm{~min}$, respectively. The following procedure for MDA determination was the same as in LPO of liver microsomes induced by $\mathrm{Fe}^{2+}$-Cys.

Determination of the decrease of GSH in mitochondria and synaptosomes induced by $\mathrm{H}_{2} \mathrm{O}_{2}$ (12): The mitochondrial and synaptosomal protein $(0.2 \mathrm{mg})$ were incubated with ISOR $\left(10^{-5}, 10^{-6}\right.$ and $\left.10^{-7} \mathrm{~mol} / \mathrm{L}\right)$, Vit E $\left(10^{-4} \mathrm{~mol} / \mathrm{L}\right)$ or vehicle in $0.5 \mathrm{ml} 0.1 \mathrm{~mol} / \mathrm{L} \mathrm{PBS}-0.5 \mathrm{mmol} / \mathrm{L}$ EDTA buffer ( $\mathrm{pH} 7.4$ ) at $37^{\circ} \mathrm{C}$ for $10 \mathrm{~min}$; then $0.2 \mathrm{mmol} / \mathrm{L} \mathrm{H}_{2} \mathrm{O}_{2}$ was added into the reaction system; and 5 min later, $50 \mu \mathrm{l}$ $0.5 \%$ Triton X-100 and $50 \mu 120 \%$ metaphosphoric acid were added. After oscillation, the incubation mixture was centrifuged at $240 \times g$ for $10 \mathrm{~min}$. The supernatant $(0.2 \mathrm{ml})$ was mixed with $1.7 \mathrm{ml}$ PBS-EDTA buffer and $0.1 \mathrm{ml} \mathrm{OPT}$ $(1 \mathrm{mg} / \mathrm{ml})$ for $15 \mathrm{~min}$. The fluorescence intensity of GSH was determined at emission wavelength $420 \mathrm{~nm}$ and excitation wavelength $350 \mathrm{~nm}$ on a MPF-4 Fluorescence Spectrophotometer (Hitachi, Tokyo). The GSH standard curve was made by the above-described method.

Effect of ISOR on the ultra-weak chemiluminescence of oxidative DNA damage induced by $\mathrm{CuSO}$-Phen-VitC- $\mathrm{H}_{2} \mathrm{O}_{2}$ system (13)

DNA $(1 \mu \mathrm{g})$ was mixed with the $\mathrm{CuSO}_{4}$-Phen-VitC$\mathrm{H}_{2} \mathrm{O}_{2}$ system $\left(5 \times 10^{-5} \mathrm{~mol} / \mathrm{L} \quad \mathrm{CuSO}_{4}, 3.5 \times 10^{-4} \mathrm{~mol} / \mathrm{L}\right.$ Phen, $3.5 \times 10^{-4} \mathrm{~mol} / \mathrm{L}$ Vit $\left.\mathrm{C}, \mathrm{H}_{2} \mathrm{O}_{2} 0.5 \%\right)$ and ISOR $\left(10^{-7}\right.$, $10^{-6}, 10^{-5}$ and $10^{-4} \mathrm{~mol} / \mathrm{L}$ ) or vehicle in $1 \mathrm{ml} 0.1 \mathrm{~mol} / \mathrm{L}$ sodium acetate-acetic acid ( $\mathrm{pH}$ 5.5) buffer. The ultra-weak chemiluminescence was determined immediately at room temperature. 
Data analyses and statistics

Results were expressed as the mean \pm S.D. Statistical significance was assessed by Dunnett's test. $P$ values less than 0.05 were considered to be significant statistically.

\section{RESULTS}

Effect of ISOR on MDA formation in LPO of rat liver microsomes induced by $\mathrm{Fe}^{2+}-\mathrm{Cys}$

As shown in Fig. 2, LPO of microsomes was successfully induced by the $\mathrm{Fe}^{2+}$-Cys system as the formation of MDA increased significantly. In comparison with the control, ISOR at $10^{-4}$ and $10^{-5} \mathrm{~mol} / \mathrm{L}$ significantly inhibited the formation of MDA $(P<0.01)$ by $94.7 \%$ and $97.6 \%$, respectively. The potency of ISOR was much more potent than that of Vit $\mathrm{E}$ at the same concentration $(P<0.01)$.

Effect of ISOR on the intensity of chemiluminescence of $L P O$ of rat liver microsomes induced by VitC-ADP-Fe $e^{2+}$

Lipid proxyl radicals (ROO') are produced during the LPO of microsomal membrane induced by the VitC-ADP$\mathrm{Fe}^{2+}$ system, which can be detected by the ultra-weak chemiluminescence technique. As shown in Fig. 3, the intensity of ultra-weak chemiluminescence was notably increased during LPO of microsomes induced by the VitC$\mathrm{ADP}-\mathrm{Fe}^{2+}$ system. ISOR $\left(10^{-4}, 10^{-5}\right.$ and $\left.10^{-6} \mathrm{~mol} / \mathrm{L}\right)$ significantly decreased the chemiluminescence intensity as compared with the control, indicating that ISOR also inhibited the generation of ROO during microsomal LPO induced by the VitC-ADP-Fe ${ }^{2+}$ system.

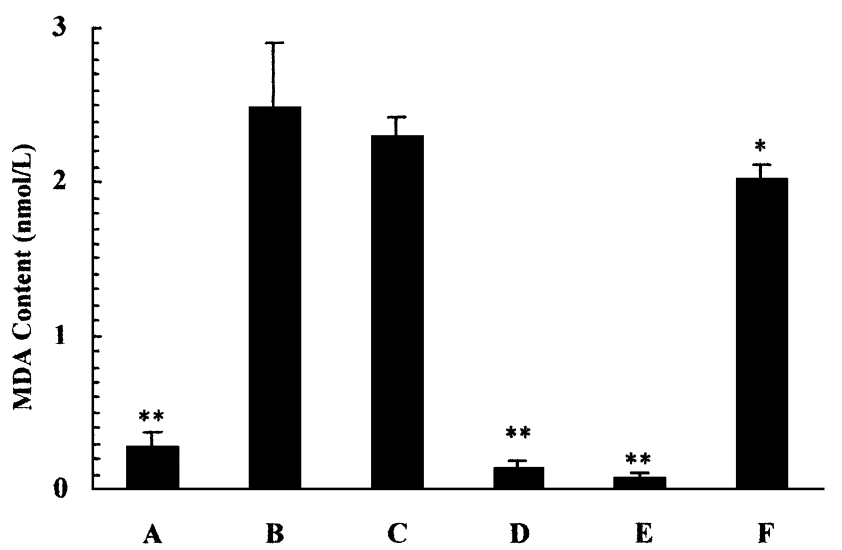

Fig. 2. Effect of isorhapontigenin on the MDA formation during liver microsomal lipid peroxidation induced by $\mathrm{Fe}^{2+}$-Cys $(n=3)$. A, Untreated microsomes; $\mathrm{B}$, microsomes treated with $\mathrm{Fe}^{2+}$-Cys only; $\mathrm{C}, \mathrm{D}, \mathrm{E}$, microsomes treated with $\mathrm{Fe}^{2+}$-Cys and isorhapontigenin at $10^{-6}, 10^{-5}$ and $10^{-4} \mathrm{~mol} / \mathrm{L}$, respectively; $\mathrm{F}$, microsomes treated with $\mathrm{Fe}^{2+}$-Cys and Vit $\mathrm{E}$ at $10^{-4} \mathrm{~mol} / \mathrm{L} . * P<0.05, * * P<0.01$ vs $\mathrm{Fe}^{2+}$ Cys control (B). Each bar is the mean \pm S.D. of 4 determinations.

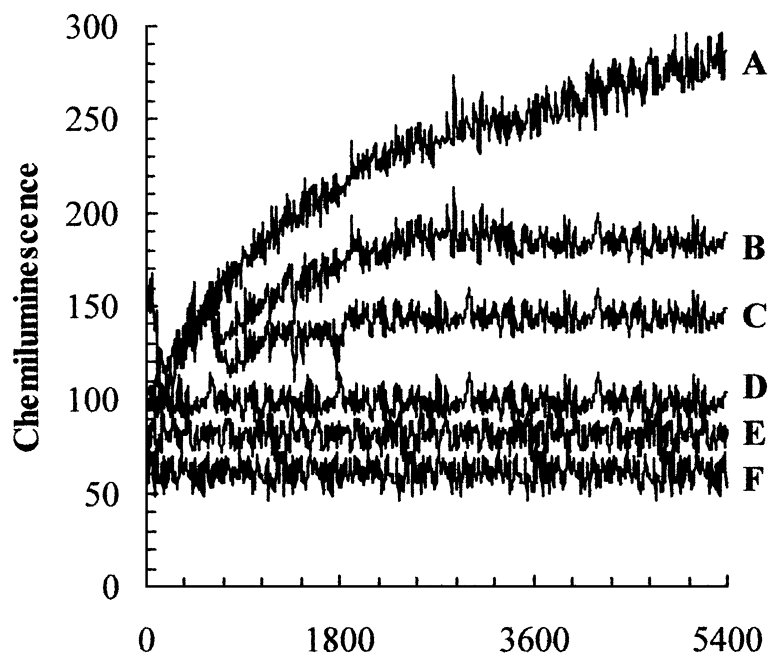

Fig. 3. Effect of isorhapontigenin on the increase of ultra-weak chemiluminescence during liver microsomal lipid peroxidation induced by VitC-ADP-Fe ${ }^{2+}$ system. A, Microsomes treated with VitC-ADP-Fe ${ }^{2+}$ system only; B, microsomes treated with VitC-ADP$\mathrm{Fe}^{2+}$ system and Vit $\mathrm{E}$ at $10^{-4} \mathrm{~mol} / \mathrm{L} ; \mathrm{C}, \mathrm{D}, \mathrm{E}$, microsomes treated with VitC-ADP-Fe ${ }^{2+}$ system and isorhapontigenin at $10^{-6}, 10^{-5}$ and $10^{-4} \mathrm{~mol} / \mathrm{L}$, respectively; $\mathrm{F}$, untreated microsomes.

Effect of ISOR on MDA formation during LPO of rat brain mitochondria and synaptosomes induced by $\mathrm{Fe}^{2+}-\mathrm{Cys}$

As indicated in Table 1, ISOR at $10^{-5}$ and $10^{-6} \mathrm{~mol} / \mathrm{L}$ significantly inhibited MDA formation during LPO of mitochondria and synaptosomes induced by the $\mathrm{Fe}^{2+}$-Cys system. ISOR at a concentration of $10^{-7} \mathrm{~mol} / \mathrm{L}$ still displayed significant inhibitory effect on MDA formation of synaptosomes $(P<0.05)$, but had no effect on that of mitochondria. The inhibitory effect of Vit $\mathrm{E}$ at $10^{-4} \mathrm{~mol} / \mathrm{L}$ on MDA formation in mitochondria and synaptosomes was less potent than that of ISOR at $10^{-6} \mathrm{~mol} / \mathrm{L}$. In other words, ISOR was almost 100 times more potent than Vit $\mathrm{E}$ in the inhibition of MDA formation.

Table 1. Effect of ISOR on MDA formation of rat brain cortex mitochondria and synaptosomes induced by $\mathrm{Fe}^{2+}$-Cys system

\begin{tabular}{lcc}
\hline & \multicolumn{2}{c}{ MDA content $\left(\mathrm{nmol} \cdot \mathrm{L}^{-1} / \mathrm{mg}\right.$ protein $)$} \\
\cline { 2 - 3 } Group & mitochondria & synaptosomes \\
\hline Normal & $8.38 \pm 7.74^{* *}$ & $9.34 \pm 7.74^{* *}$ \\
$\mathrm{Fe}^{2+}$-Cys & $24.63 \pm 11.88$ & $33.23 \pm 11.57$ \\
ISOR $10^{-5} \mathrm{~mol} / \mathrm{L}$ & $9.97 \pm 7.10^{* *}$ & $12.20 \pm 7.42^{* *}$ \\
$10^{-6} \mathrm{~mol} / \mathrm{L}$ & $15.39 \pm 7.42^{*}$ & $18.58 \pm 9.02^{*}$ \\
$10^{-7} \mathrm{~mol} / \mathrm{L}$ & $24.63 \pm 10.93$ & $21.44 \pm 7.11^{*}$ \\
Vit E $10^{-4} \mathrm{~mol} / \mathrm{L}$ & $12.52 \pm 6.79^{*}$ & $16.03 \pm 9.65^{* *}$
\end{tabular}

Data are expressed as the mean \pm S.D. of 4 determinations. Compared with the control group using Dunnett's test, ${ }^{*} P<0.05$, ${ }^{*} P<0.01$. 
Effect of ISOR on the decrease of GSH in rat cerebral cortex mitochondria and synaptosomes induced by $\mathrm{H}_{2} \mathrm{O}_{2}$

As shown in Table 2, ISOR at $10^{-5}$ and $10^{-6} \mathrm{~mol} / \mathrm{L}$ significantly prevented the decrease of GSH in mitochondria induced by $0.2 \mathrm{mmol} / \mathrm{L}_{2} \mathrm{O}_{2}(P<0.01$ and $P<0.05$, respectively), while ISOR at $10^{-5}, 10^{-6}$ and $10^{-7} \mathrm{~mol} / \mathrm{L}$ all markedly prevented GSH decrease in synaptosomes $(P<0.01)$. The preventive effect of Vit $\mathrm{E}$ at $10^{-4} \mathrm{~mol} / \mathrm{L}$ on the decrease of mitochondrial and synaptosomal GSH corresponded to that of ISOR at $10^{-5} \mathrm{~mol} / \mathrm{L}$.

Protective effect of ISOR on the oxidative DNA damage induced by $\mathrm{CuSO}_{4}$-Phen-VitC- $\mathrm{H}_{2} \mathrm{O}_{2}$

Free guanines produced during breakage of the DNA doublestrand induced by oxidative damage possess characteristic ultra-weak chemiluminescence that reflects the extent of DNA damage indirectly. As shown in Fig. 4, the characteristic ultra-weak chemiluminescence of guanines markedly increased during oxidative DNA damage induced by $\mathrm{CuSO}_{4}$-Phen-VitC- $\mathrm{H}_{2} \mathrm{O}_{2}$ system. ISOR $\left(10^{-7}, 10^{-6}, 10^{-5}\right.$ and $10^{-4} \mathrm{~mol} / \mathrm{L}$ ) markedly reduced the chemiluminescence in a dose-dependent manner, particularly ISOR at $10^{-5}$ and $10^{-4} \mathrm{~mol} / \mathrm{L}$ almost completely decreased the production of chemiluminescence.

\section{DISCUSSION}

Various reactive oxygen species (ROS) are generated from enzymatic or nonenzymatic processes during the normal metabolism in cells. If excessive ROS are not eliminated promptly, the accumulation of ROS can produce cytotoxic effects (14). Lipid peroxidation of polyunsaturated fatty acids (PUFA) in the biomembranes are prone to be initiated by ROS, which leads to impairment of biomembrane structure and functions. In the present study, $\mathrm{Fe}^{2+}-\mathrm{Cys}$ and VitC-ADP-Fe ${ }^{2+}$ systems were used to generate ROS for initiating LPO of liver microsomes, brain mitochondria and synaptosomes. In the early stage of the LPO process, the

Table 2. Effect of ISOR on decrease of glutathione (GSH) in rat brain mitochondria and synaptosomes induced by $\mathrm{H}_{2} \mathrm{O}_{2}$

\begin{tabular}{lll}
\hline \multirow{2}{*}{ Group } & \multicolumn{2}{c}{ GSH content $(\mu \mathrm{g} / \mathrm{mg}$ protein $)$} \\
\cline { 2 - 3 } Normal & mitochondria & synaptosomes \\
Control & $2.51 \pm 0.05^{* *}$ & $4.14 \pm 0.14^{* *}$ \\
ISOR $10^{-5} \mathrm{~mol} / \mathrm{L}$ & $1.86 \pm 0.03$ & $2.54 \pm 0.08$ \\
$10^{-6} \mathrm{~mol} / \mathrm{L}$ & $1.94 \pm 0.04^{*}$ & $3.34 \pm 0.21^{* *}$ \\
$10^{-7} \mathrm{~mol} / \mathrm{L}$ & $1.99 \pm 0.17$ & $2.97 \pm 0.26^{* *}$ \\
Vit E $10^{-4} \mathrm{~mol} / \mathrm{L}$ & $2.21 \pm 0.04^{* *}$ & $2.79 \pm 0.08^{* *}$ \\
\hline
\end{tabular}

Data are expressed as the mean \pm S.D. of 4 determinations. Compared with the control group using Dunnett's test, ${ }^{*} P<0.05$, ${ }^{* *} P<0.01$.

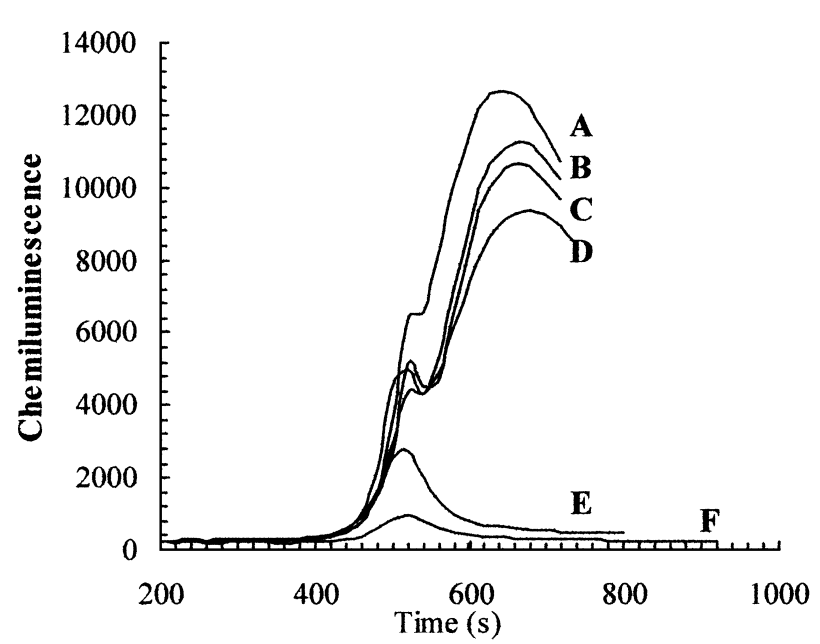

Fig. 4. Effect of isorhapontigenin on the increase of ultra-weak chemiluminescence during oxidative DNA damage induced by $\mathrm{CuSO}_{4}$-Phen-VitC- $\mathrm{H}_{2} \mathrm{O}_{2}$ system. A, Control, DNA treated with $\mathrm{CuSO}_{4}$-Phen-VitC- $\mathrm{H}_{2} \mathrm{O}_{2}$ system; C, DNA treated with $\mathrm{CuSO}_{4}$-PhenVitC- $\mathrm{H}_{2} \mathrm{O}_{2}$ system and vit $\mathrm{E}$ at $10^{-4} \mathrm{~mol} / \mathrm{L} ; \mathrm{B}, \mathrm{D}, \mathrm{E}$ and $\mathrm{F}$, DNA treated with $\mathrm{CuSO}_{4}-\mathrm{Phen}-\mathrm{VitC}-\mathrm{H}_{2} \mathrm{O}_{2}$ system and isorhapontigenin at $10^{-7}, 10^{-6}, 10^{-5}$ and $10^{-4} \mathrm{~mol} / \mathrm{L}$, respectively.

secondary ROO ${ }^{*}$ of PUFA is highly susceptible to peroxidative breakdown (9) and may internally cyclize to form a five-member endoperoxide, which is assumed to decompose to low molecular weight ketones and aldehydes, predominantly MDA. Mitochondria and synaptosomes are important organelles; particularly, mitochondria are the energy plant of cells and are an abundant source of ROS, allowing the occurrence of plentiful biochemical reactions. Consequently, the double-membrane layers of mitochondria are the susceptible target of ROS attack. Our results showed that ISOR even at $10^{-6} \mathrm{~mol} / \mathrm{L}$ could significantly inhibit MDA formation during biomembrane LPO induced by $\mathrm{Fe}^{2+}$-Cys, and the anti-MDA formation of ISOR is about 100 times more potent than that of the classical antioxidant $\mathrm{Vit} \mathrm{E}$ at the same concentration. It appears that ISOR could protect cell organelles against oxidative damage at the early stage of the LPO process.

All secondary ROO of LPO can act as potential precursors of photoemissive species (9). At a later stage of LPO, collision of two ROO' is assumed to generate two different electronically excited species, singlet molecular oxygen $\left({ }^{1} \mathrm{O}_{2}\right)$ and a compound in the triplet state $\left({ }^{3} \mathrm{R}=\mathrm{O}\right)$. Photons are generated during conversion of ${ }^{3} \mathrm{R}=\mathrm{O}$ into $\mathrm{R}=\mathrm{O}$, termed as ultra-weak chemiluminescence, which can be regarded as one branch of LPO occurring later than MDA formation. In the present study, the intensity of ultraweak chemiluminescence significantly increased during microsomal LPO induced by the VitC-ADP- $-\mathrm{Fe}^{2+}$ system. ISOR at $10^{-5}$ and $10^{-4} \mathrm{~mol} / \mathrm{L}$ almost inhibited this reaction completely, and even ISOR at the concentration of $10^{-6} \mathrm{~mol}$ 
/L was still effective, suggesting that ISOR could prevent microsomes from oxidative damage at the later stage of LPO.

GSH plays an important role in eliminating ROS in cells. Besides oxidative damage during the LPO chain reaction, ROS can cause lesions in biomacromolecules such as proteins through other pathways (15):

$$
2 \mathrm{GSH}+\mathrm{ROS}\left(\mathrm{H}_{2} \mathrm{O}_{2}\right) \stackrel{\text { GSH peroxidase }}{\longrightarrow} \mathrm{GSSG}+2 \mathrm{H}_{2} \mathrm{O}
$$

Thioltransferase or thioredoxin

$\mathrm{GSSG}+$ Protein-SH $\longrightarrow \mathrm{GSH}+$ Protein-SSG

Although removal of $\mathrm{H}_{2} \mathrm{O}_{2}$ by GSH and GSH peroxidase extinguishes a direct oxidative threat to cells, formation of GSSG can bring deleterious consequences. GSSG reacts spontaneously with thiol groups in proteins (Protein-SH) to form protein mixed disulfides (Protein-SSG). When the affected protein thiols are essential for biologic activity, their functions will be suppressed, such as in the cases of succinate dehydrogenase, NADH dehydrogenase, ATPase, isocitrate dehydrogenase and succinate-supported mitochondrial electron transport, enzymes that are all essential for energy metabolism $(16,17)$. Through the LPO and GSSG pathways, ROS induces essential enzymes suppression and leakage, and eventually, energy metabolism is arrested and cellular viability is decreased. Our results showed that ISOR not only significantly protected rat brain mitochondria and synaptosomes against LPO damage, but also reduced the consumption of endogenous antioxidant GSH, possibly as a result, the damage to thiol proteins induced by GSSG accumulation may be alleviated.

Oxidative damage to DNA induced by ROS can occur through many routes including the oxidative modification of the nucleotidebases and sugars or by forming crosslinks. Such modifications may lead to mutation, carcinogenesis, cellular aging and death (18). A recent study (19) suggested that the brain in $\mathrm{AD}$ and aged people may be subject to the insult of oxidative stress, and an increase in levels of brain DNA oxidation exists in both aging and AD. The level of 8-hydroxy-2'-deoxyguanosine (8-OH-dG) has been regarded as the predominant marker of oxidative DNA damage, and significant elevations of free 8-OH-dG were observed in celebrospinal fluid of $\mathrm{AD}$ subjects as compared with age-matched control subjects. Various antioxidants could markedly reduce the level of $8-\mathrm{OH}-\mathrm{dG}$ during oxidative DNA damage induced by ROS (20). As shown in the present study, hydroxyl free radicals generated in the $\mathrm{CuSO}_{4}$-Phen-VitC- $\mathrm{H}_{2} \mathrm{O}_{2}$ system caused oxidative DNA damage expressed in the remarkable increase of characteristic ultra-weak chemiluminescence of free guanines. ISOR significantly decreased the intensity of luminescence during oxidative DNA damage induced by the system, suggesting that ISOR could prevent oxidative DNA damage induced by ROS. By using the electron spin resonance (ESR) technique, Fang found that ISOR has the activity to scavenge $\mathrm{O}_{2}^{-}$and ${ }^{\circ} \mathrm{OH}$ in activated neutrophils (studies performed as part of the dissertation of YN Fang: Effect of isorhapontigenin and several related compounds on neutrophil's function and the oxidation of low density lipoprotein, Chinese Academy of Medical Sciences and Peking Union Medical College, Beijing (1997)). All the above results suggest that ISOR has protective action against ROS oxidative damage at different levels.

\section{Acknowledgment}

The present study was supported by a grant (No. G2000057010) from the Chinese Ministry of Sciences and Technology.

\section{REFERENCES}

1 Fremont L: Biological effects of resveratrol. Life Sci 66, $663-673(2000)$

2 Basly JP, Marre-Fournier F, Le Bail JC, Habrioux G and Chulia AJ: Estrogenic/antiestrogenic and scavenging properties of (E)- and (Z)-resveratrol. Life Sci 66, 769 - 777 (2000)

3 Draczynska-Lusiak B, Doung A and Sun AY: Oxidized lipoproteins may play a role in neuronal cell death in Alzheimer disease. Mol Chem Neuropathol 33, 139 - 148 (1998)

4 Li JB, Lin M, Li SZ and Song WZ: Studies on the structure of gnetifolin A of Gnetum parvifolium (Warb.) C.Y.Cheng. Acta Pharm Sin 6, 437 - 441 (1991)

5 Zhou LX and Lin M: A new stilbene dimer-shegansu B from Belamcanda chinensis. J Asian Nat Prod Res 2, 169-175 (2000)

$6 \mathrm{Lu} \mathrm{H}$ and Liu GT: Anti-oxidant activity of dibenzocyclooctene lignans isolated from Schisandraceae. Planta Med 58, 311 - 313 (1992)

7 Lowry OH, Rosebrough NJ, Farr AL and Randall RJ: Protein measurement with the Folin phonol reagent. J Biol Chem 193, $265-275$ (1951)

$8 \mathrm{Lu} \mathrm{H}$ and Liu GT: Effect of dibenzo[a,c]cyclooctene lignans isolated from Fructus schizandrae on lipid peroxidation and anti-oxidative enzyme activity. Chem Biol Interact 78, $77-84$ (1991)

9 Noll T, DE Groot H and Sies H: Distinct temporal relation among oxygen uptake, malondialdehyde formation, and lowlevel chemiluminescence during microsomal lipid peroxidation. Arch Biochem Biophys 252, 284 - 291 (1987)

10 Dodd PR, Hardy JA, Oakley AE, Edwardson JA, Perry EK and Delaunoy JP: A rapid method for preparing synaptosomes: comparison with alternative procedures. Brain Res 226, $107-$ 118 (1981)

11 Buege JA and Aust SD: Microsomal lipid peroxidation. Methods Enzymol LII, $301-310$ (1978)

12 Hissin PJ and Hilf A: Fluorometric method for determination of oxidized and reduced glutathione in tissues. Anal Biochem 74, $214-225$ (1976)

13 Zhang J, Cao EH and Qin JF: Study of mechanism of antioxidant protection against DNA damage. Acta Biophys Sin 13, $123-$ 127 (1997)

14 Simonian NA and Coyle JT: Oxidative stress in neurodegenera- 
tive diseases. Annu Rev Pharmacol Toxicol 36, 83 - 106 (1996)

15 Rabenstein DL and Millis KK: Nuclear magnetic resonance study of the thioltransferase-catalyzed glutathione/glutathione disulfide interchange reaction. Biochim Biophys Acta 1249, 29 - 36 (1995)

16 Benard $\mathrm{O}$ and Balasubramanian KA: Effect of oxidized glutathione on intestinal mitochondria and brush border membrane. Int J Biochem Cell Biol 27, 589 - 595 (1995)

17 Berridge MV and Tan AS: Characterization of the cellular reduction of 3-(4,5-dimethylthiazol-2-yl)-2,5-diphenyltetrazolium bromide (MTT): subcellular localization, substrate depend- ence, and involvement of mitochondrial electron transport in MTT reduction. Arch Biochem Biophys 303, 474 - 482 (1993)

18 Gracy RW, Talent JM, Kong Y and Conrad CC: Reactive oxygen species: the unavoidable environmental insult? Mutat Res 428, 17 - 22 (1999)

19 Lovell MA, Gabbita SP and Markesbery WR: Increased DNA oxidation and decreased levels of repair products in Alzheimer's disease ventricular CSF. J Neurochem 72, 771 - 776 (1999)

20 Collins AR: Oxidative DNA damage, antioxidants, and cancer. Bioessays 21, 238 - 246 (1999) 